\title{
Research Paper Post-harvest losses in the mango supply channel in Tamil Nadu state, India
}

C. Sekar

Correspondence to :

\section{Sekar}

Department of Agricultural Economics, Centre for Students' Welfare, Tamil Nadu Agricultural University, Coimbatore (T.N.) India Email: csekar2000@gmail. com

\section{Paper History :}

Received : 19.06.2020;

Revised : 20.07.2020;

Accepted : 21.08 .2020
ABSTRACT : A study was conducted to identify mango value chains and analyse the post-harvest losses along them in the major mango-growing areas of Tamil Nadu state in India. The post-harvest losses were estimated using survey data collected during 2016-17 from 400 farmers; 60 households; and 100 traders consisting of wholesalers, commission agents, exporters, processors and retailers and 60 consumers in Tamil Nadu. Six major mango value chains were found in the production catchments through which the mango fruits reached consumers in different forms. Overall, the post-harvest losses at the farm level were estimated at 7.08 per cent. At the primary wholesaler level the losses were estimated at 7.30 per cent and at the processing level at 8.70 per cent. At the secondary wholesaler level the losses were estimated at 10 per cent. Maximum losses were observed at the retail level (14.97\%), most likely as a result of improper post-harvest handling, lack of proper storage facilities, and rough handling of fruits by consumers who check fruit quality by squeezing. It is recommended that establishing procurement yards near farms, minimizing transaction points in the mango value chain, establishing value added and processing units near production catchments, initiating farmer cooperatives similar to Anand Milk Union Limited (AMUL) in India model, involving collection of fruits directly from the farmers by cooperatives, initiating Farmer Producer Company (FPC) and establishing a refrigerated transport system for well graded fruits right from farm to consumption centres would minimize post-production losses of mango.

KEY WORDS : Economic analysis, Post-harvest losses, Mango supply channel, Value chain, Market intermediaries, Market actors

How To Cite This Paper: Sekar, C. (2020). Post-harvest losses in the mango supply channel in Tamil Nadu state, India. Internat. Res. J. Agric. Eco. \& Stat., 11 (2) : 217-225, DOI : 10.15740/HAS/IRJAES/11.2/217-225. Copyright@2020:Hind Agri-Horticultural Society. 